\title{
COMPOSITION AND DIVERSITY OF WEEDS IN PEAT SWAMP FOREST IN BANJAR DISTRICT OF SOUTH KALIMANTAN, INDONESIA
}

\author{
Susilawati*, Asysyifa, Researchers \\ Oktoviani Ira, Student \\ Study Program of Forestry, Faculty of Forestry, University of Lambung Mangkurat, \\ South Kalimantan, Indonesia \\ *E-mail: susilawati@ulm.ac.id
}

\begin{abstract}
Indonesia is one of the countries that have very diverse biological resources. This diversity is often found in forest areas, one of which is peat swamp forest. This research was conducted in peat swamp forest in Guntung Ujung Village, Gambut District, located in Banjar Regency, South Kalimantan. This study aims to identify weeds by calculating the values of Relative Density (KR), Relative Frequency (FR), Relative Dominance (DR), Important Value (NP) and Summed Dominance Ratio (SDR) and analyzing the weed diversity index in peat swamp forest areas. The research data collection was obtained from taking samples to the field by making an observation plot of $1 \mathrm{~m}^{2}$ and the distance between the plots was $10 \mathrm{~m}^{2}$. Plants found in the observation plot are taken as the observation sample used for the calculation of NP (Importance Value) and plant diversity index (using the Shannon-Wiener species diversity index). Based on the results of research on the species composition and diversity of weeds, it can be concluded that there are 18 types of weeds found in the peat swamp forest, Banjar Regency in 10 total observation plots with 12 families and 2 of them have not been identified, namely Spinach Rosa and Sasuangan. The plant species with the highest NP was Kelakai (Stenochelaena palustris) at $60.13 \%$ and the resulting diversity of species was 1.05 which was included in the medium category.
\end{abstract}

\section{KEY WORDS}

Composition, diversity, peat, weeds, vegetation analysis, important value.

Indonesia is a country that has very diverse biological resources or ecosystem diversity. Biodiversity is a variation of the differences between living things which can be in plants, animals, and microorganisms, besides that it can also be in the genetic material they contain, as well as the forms of ecosystems in which a living thing lives (Ridhwan, 2012). Biodiversity is often referred to differences which can occur due to differences in color, size, shape, number, texture, appearance and other characteristics.

This diversity is often found in forest areas. Law No. 41 of 1999 concerning Forestry defines forest as a large expanse of land which is a unitary ecosystem and contains biological natural resources and dominated by types or types of trees in association with one another which cannot be separated. In Indonesia, there are several types of forest with all the characteristics of the ecosystem in them, one of which is peat swamp forest.

Guntung Ujung is a village name which is located in Gambut District, Banjar Regency, South Kalimantan. In the area of Guntung Ujung Village, there is an area of peat forest which has biodiversity and is overgrown with various types of plants, from seedlings to tree levels, as well as weeds and understorey covering the soil surface. Aththorick (2005) states that understorey plants are plants that compose subsurface stratification near the surface of the soil, which can usually be used for medicine and foodstuffs, while weeds according to Aldrich (1984) are plants that come from the natural environment and continuously interfere with plants and 
human activities in cultivate cultivated plants.

Based on the above statement, it is necessary to conduct research on peat swamp forest in Guntung Ujung Village, Gambut District, located in Banjar Regency, South Kalimantan. This study aims to identify weeds by calculating the values of Relative Density (KR), Relative Frequency (FR), Relative Dominance (DR), Important Value (NP) and Summed Dominance Ratio (SDR) and analyzing the weed diversity index in peat swamp forest areas.

\section{METHODS OF RESEARCH}

This research was conducted in the area of Peat Swamp Protected Forest, Banjar Regency, in March-April 2021. It covers the stages of activities, namely preparation, data collection in the field and data processing for research reports. The tools and materials that will be used in this research are ropes, meters, machetes, stationery, tally sheets, cameras, GPS, plastic bags, digital scales, ovens, species identifiers, and weeds in the research location.

The research data collection was obtained from taking samples to the field by making an observation plot of $1 \mathrm{~m}^{2}$ and the distance between the plots was $10 \mathrm{~m}^{2}$. Plants found in the observation plot are taken as the observation sample used for the calculation of NP (Importance Value) and plant diversity index (using the Shannon-Wiener species diversity index).

Data processing is done by performing calculations with the following formula:

a) Density of One Species $(K)=\frac{\text { Number of individual of one species }}{\text { The area of observation plot }}$

b) Relative Density of One Species $(K R)=\frac{\text { Density of one species }}{\text { Density of all speciess }} \times 100$

c) Frequency of One Species $(F)=\frac{\text { the number of plots occupied by one species }}{\text { Number of the observaton plots }}$

d) Relative Frequency of One Species $(F R)=\frac{\text { Frequency of one species }}{\text { Frequency of all speciess }} \times 100$

e) Dominance of One Species $(D)=\frac{\text { Dry weight of one species }}{\text { The area of observation plot }} \times 100$

f) Relative Dominance of One Species $(D R)=\frac{\text { Dominance of one species }}{\text { Dominance of all speciess }} \times 100$

g) Important score (NP) $=\mathrm{KR}+\mathrm{FR}+\mathrm{DR}$

h) Summed Dominance Ratio $(\mathrm{SDR})=\frac{N P}{3}$

i) Diversity Index:

$$
H^{\prime}=-\sum_{i=1}^{n}\left[\frac{n_{i}}{N} \ln \frac{n_{i}}{N}\right]
$$

Where: $\mathrm{H}$ '= Shannon-Wiener Diversity Index; $\mathrm{ni}=$ number of individual species-i, and $\mathrm{N}=$ Total number of individuals of all species.

\section{RESULTS AND DISCUSSION}

The results of field observations, found as many as 18 species of weeds from 12 families with a total clump of 275 clumps included in the 10 observation plots in the field. Of the 18 weed species found in the field, 2 species were not identified, namely Sasuangan and Bayam Rosa. 
The composition of the types and number of weed species is presented in Table 1 below.

Table 1 - Composition of Species and Number of Weed Species

\begin{tabular}{lllll}
\hline No. & Name of Species & Total number & Botanical Name & Family \\
\hline 1 & Anggrek Tanah & 11 & Bletilla striata & Orchidaceae \\
2 & Bandotan & 3 & Ageratum conyzoides & Asteraceae \\
3 & Bayam rosa & 4 & - & Poaceae \\
4 & Ilalang & 5 & Imperrata cylindrica & Calophyllaceae \\
5 & Kapur Naga & 4 & Calophyllum soulattri & Myrtaceae \\
6 & Karamunting & 19 & Malestoma affine & Blechnaceae \\
7 & Kelakai & 55 & Stenochelaena palustris & Asteraceae \\
8 & Kerinyuh & 2 & Chromolaena odorata & Cyperaceae \\
9 & Laladingan & 5 & Cyperus esculentus & Lygodiaceae \\
10 & Litu/Ribu-ribu & 50 & Lygodium scandens & Pteridaceae \\
11 & Paku piai & 5 & Acrostichum aureum & Onagraceae \\
12 & Papisangan & 10 & Ludwigia adscendens & Cyperaceae \\
13 & Purun Tikus & 33 & Lepironia articulata & Primulaceae \\
14 & Rumput Fatimah & 4 & Labisia pumila & Schizaeaceae \\
15 & Sampairingan & 33 & Schizaea digitate & Poaceae \\
16 & Sasuangan & 3 & - & Poaceae \\
17 & Sarapangan & 13 & Cymbopogon nardus & \\
18 & Serai Merah & 16 & &
\end{tabular}

Based on Table 1 are the most commonly found plants in the field, namely 55 plants for Kelakai species and 50 plants for Litu/Ribu-ribu species, then following Purun species. Purun Tikus (Lepironia articulata) and Sampairingan (Schizaea digitate) with 33 plant clumps. When viewed from the family, the largest number of species found were from the Blechnaceae, Lygodiaceae, and Cyperaceae families. Each of these species is as much as 55, 50, and 38 plants. The following graph of the number of species by family is presented in Figure 1 below.

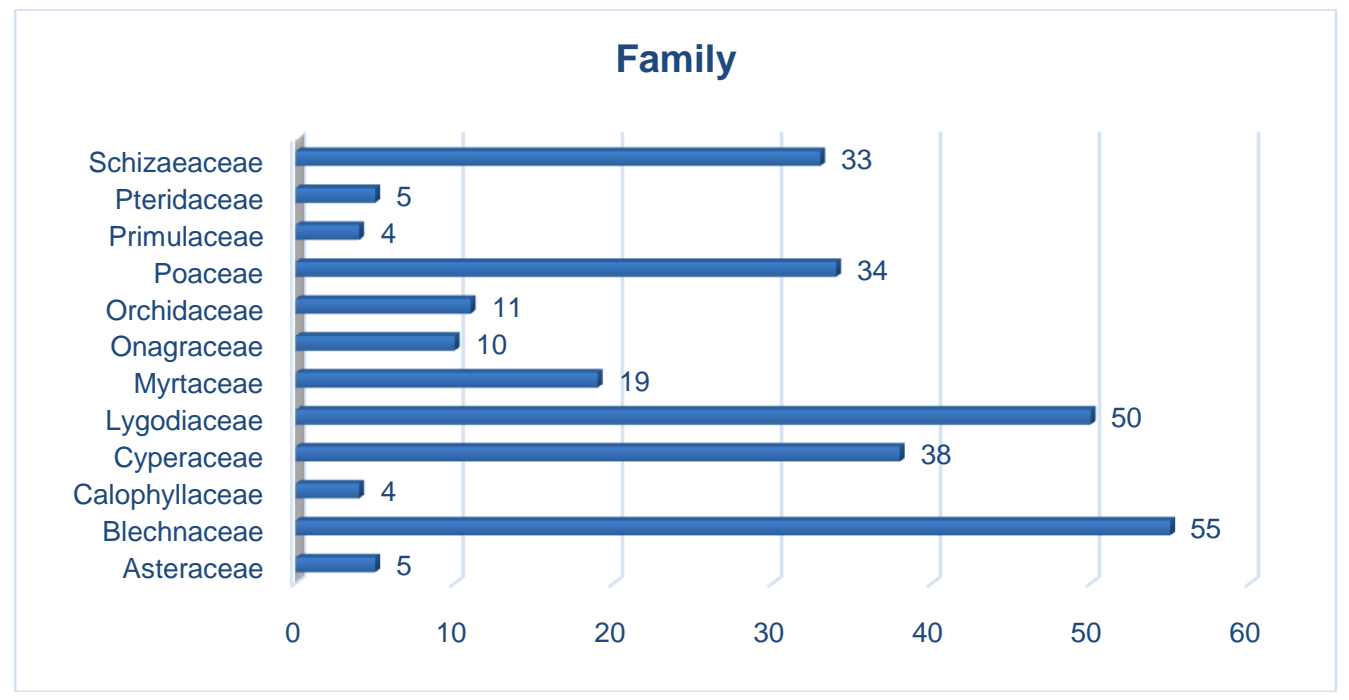

Figure 1 - Number of Species by Family

Based on the results above, it shows that there are differences in the structure and composition of vegetation in a forest area which according to Bibiana et al., (2015) these differences occur due to changes in vegetation that occur continuously due to the presence of certain types that are missing or dead and there are also types. -new types that appear, so that the old population will be replaced by the new population. Furthermore, according to Suyanti et al., (2018) the existence of diversity that exists and does not exist because it is caused by soil 
conditions, or soil texture, soil levels from climate and soil in the research locations are very diverse. This statement implies that environmental factors greatly influence the emergence of plants in an area, so that in each plot, different types and numbers of plants can be found.

Vegetation analysis is a way to learn about the structure and composition of vegetation based on its shape. The following are the results of the weed analysis in Table 2 as follows:

Table 2 - Weed Vegetation Analysis Results

\begin{tabular}{lllll}
\hline Name of Species & Total Number & KR $(\%)$ & FR (\%) & DR (\%) \\
\hline Anggrek Tanah & 11 & 4,00 & 6,12 & 5,04 \\
Bandotan & 3 & 1,09 & 2,04 & 0,45 \\
Bayam rosa & 4 & 1,45 & 2,04 & 2,16 \\
llalang & 5 & 1,82 & 2,04 & 1,42 \\
Kapur Naga & 4 & 1,45 & 4,08 & 1,53 \\
Karamunting & 19 & 6,91 & 14,29 & 5,52 \\
Kelakai & 55 & 20,00 & 16,33 & 23,80 \\
Kerinyuh & 2 & 0,73 & 2,04 & 0.66 \\
Laladingan & 5 & 1,82 & 2,04 & 1,41 \\
Litu/Ribu-ribu & 50 & 18,18 & 6,12 & 19,81 \\
Paku piai & 5 & 1,82 & 2,04 & 1,65 \\
Papisangan & 10 & 3,64 & 6,12 & 3,46 \\
Purun Tikus & 33 & 12,00 & 6,12 & 11,76 \\
Rumput Fatimah & 4 & 1,45 & 2,04 & 1,08 \\
Sampairingan & 33 & 12,00 & 12,24 & 10,50 \\
Sasuangan & 3 & 1,09 & 2,04 & 0,88 \\
Sarapangan & 13 & 4,73 & 4,08 & 2,80 \\
Serai Merah & 16 & 5,82 & 8,16 & 6,08 \\
\hline
\end{tabular}

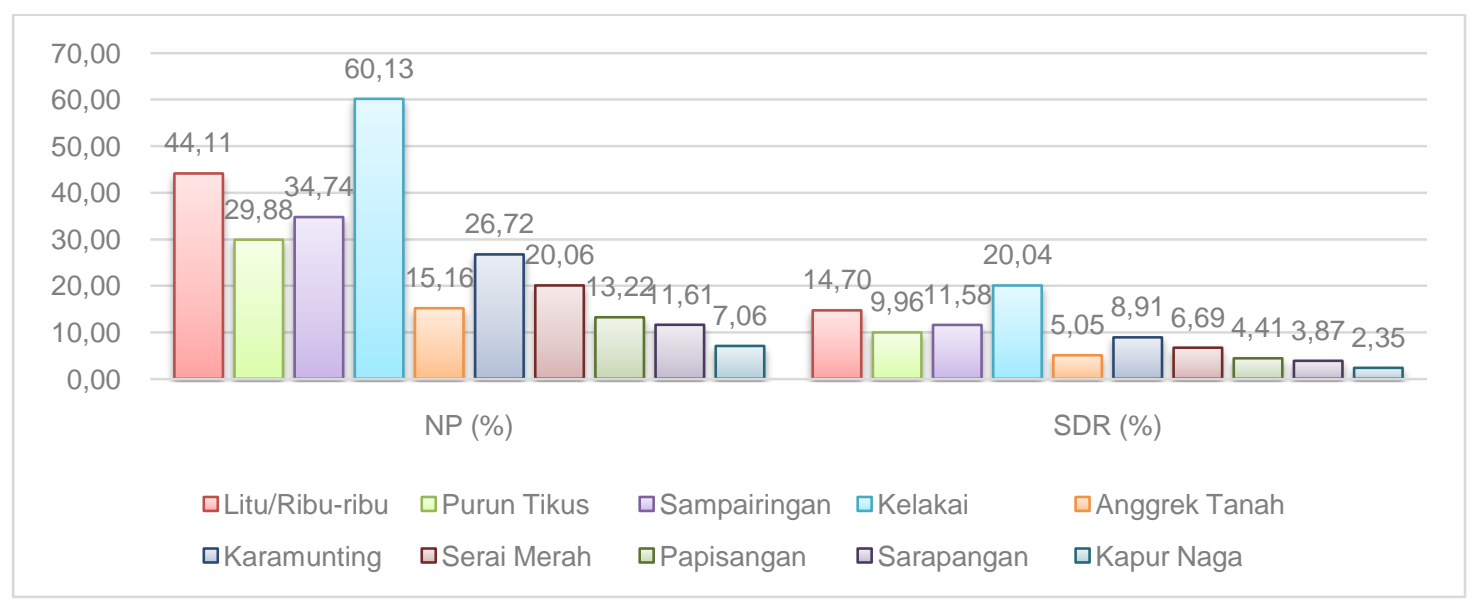

Figure 2 - Graph of Top 10 Weeds Importance Value Index (NP) and Summed Dominance Ratio (SDR)

This vegetation analysis was carried out on weeds with a plot area of $1 \mathrm{~m} \times 1 \mathrm{~m}$. The number of observation plots is 10 plots. The Relative Density Value (KR) is obtained from the comparison between the density value of a species and the density value of all species, and then multiplied by $100 \%$, where the density value is influenced by the number of individuals of a type and the area of the plot, while the Relative Frequency (FR) value is obtained from the calculation. between the frequency value of a type divided by the frequency value of all types then multiplied by $100 \%$, where the frequency value is influenced by the number of plots of a type and the number of all plots, while the Relative Dominance Value (DR) is the result of a comparison between the dominance value of a species and the dominance value. All species are then multiplied by $100 \%$, in which the dominance value is influenced by the dry weight of a type and the area of the observation plot, while the dry weight value is obtained from the 
weighing of plant samples that have been heated in the oven with a temperature of $70^{\circ} \mathrm{C}$ for \pm 12 hours until it is constant. In addition, an important value index (NP) and Summed Dominance Ratio (SDR) are also needed. The following graph of weeds which have the highest NP and SDR 10 is presented in Figure 2.

Important Value (NP) is influenced by the value of Relative Density (KR), Relative Frequency (FR), and Relative Dominance (DR), so that the greater the value of KR, FR and DR, the NP is also large and vice versa if the values of KR, FR and DR are small then the NP is also small. In Figure 2, it can be seen that the highest NP and SDR are Kelakai, namely $60.13 \%$ and $20.04 \%$, the second highest NP is Litu/Ribu-ribu namely $44.11 \%$ and $14.70 \%$, and the third highest NP is Sampairingan. $34.74 \%$ and $11.58 \%$. NP is a quantitative parameter that can be used to express the level of dominance (level of control) of species in a plant community (Soegianto, 1994), so that the greater the NP, the greater the level of control and vice versa. This statement also applies to SDR values, because NP and SDR are always directly proportional.

Naemah et al., (2020) stated that the density and frequency values are not always proportional to the dominance value because this value is influenced by the dry weight of the species. This statement is in line with the research results shown in the following figure.

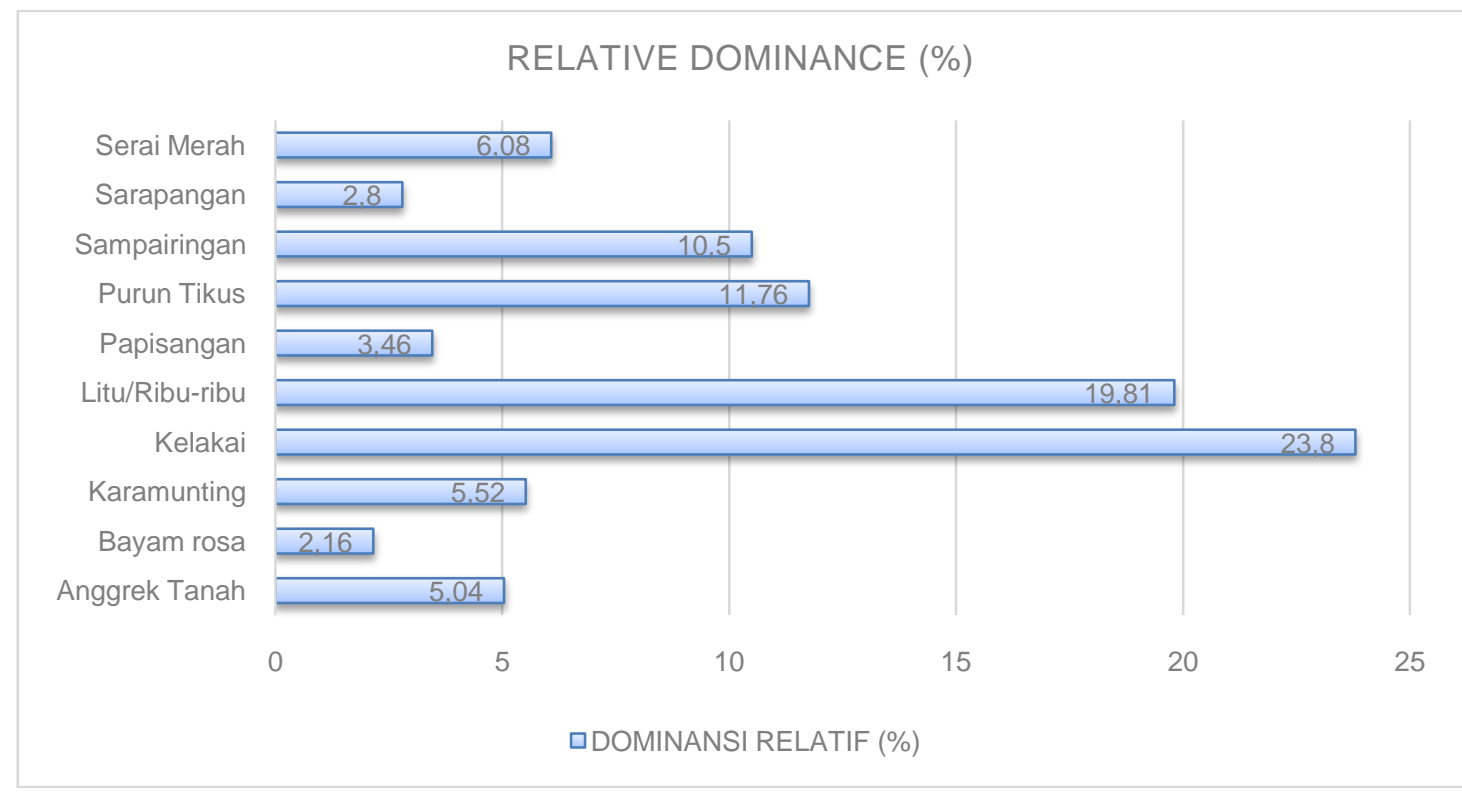

Figure 3 - Graph 10 Highest Weed Relative Dominance Value

The data presented in Figure 2 and Figure 3, if sorted by plant species from the largest to the smallest value, namely, in Figure 2 starting with the species of Kelakai (Stenochelaena palustris), Litu / Thousand-thousand (Lygodium scandens), Sampairingan (Schizaea digitata) Purun Tikus (Eleocharis dulcis), Karamunting (Malestoma affine), Serai Merah (Cymbopogon nardus), Anggrek Tanah (Bletilla striata), Papisangan (Ludwigia adscendens), Sarapangan (Melinis repens), and Kapur Naga (Calophyllum soulattri), while in the picture 3, namely the species of Kelakai, Litu / Ribu-ribu, Purun Tikus, Sampairingan, Serai Merah, Karamunting, Tanggrek Tanah, Papisangan, Sarapangan (Melinis repens), and Bayam Rosa. If you compare the two pictures, you can see the differences in the 3rd, 4th, 5th, 6th, and 10th order. The 10th place in Figure 2 is the species of Kapur Naga, while in Figure 3 is the species of Bayam Rosa. Furthermore, the species of plants that have the 5 highest important values (NP) can be seen in Figure 4. 


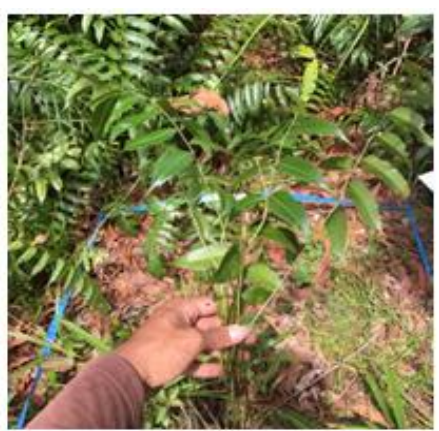

(a)

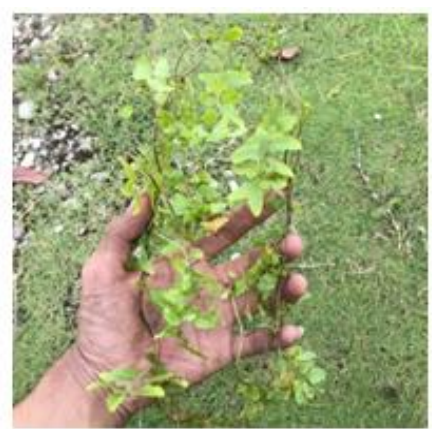

(b)

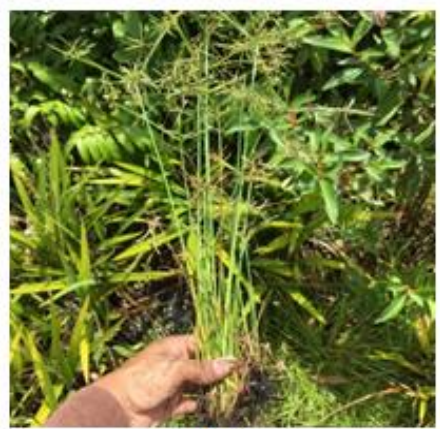

(c)

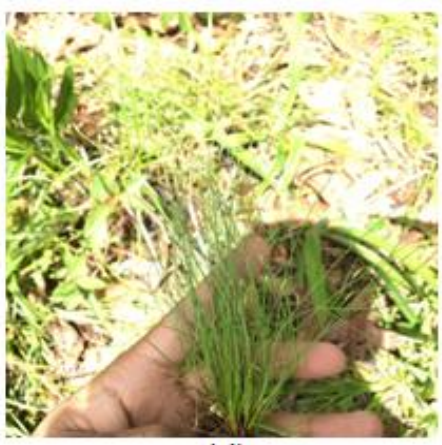

(d)

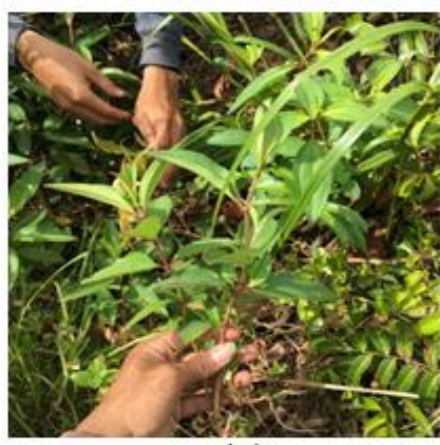

(e)

Figure 4 - Kelakai (a), Litu /Ribu-ribu (b), Sampairingan (c), Purun Tikus (d), and Karamunting (e)

The diversity of a plant community species can be determined using the Shannon-Wiener formula. Species diversity can be used to express community structure (Indriyanto, 2006). Furthermore, according to Soegianto, (1994), species diversity can also be used to measure community stability, namely the ability of a community to keep itself stable despite interference with its components. Based on the results of the analysis of species diversity, it states that the diversity of weeds found in the study site is categorized as moderate, namely 1.05 because according to Shannon-Wiener in Fachrul (2012) if $\mathrm{H}^{\prime} 1 \leq \mathrm{H}^{\prime} \leq 3$ indicates that species diversity in the area is moderate. Overflow. The results of weed species diversity can be seen in Table 3 .

Based on these results, it shows that the condition of the plants in the protected forest area of the peat swamp in Banjar Regency has moderate productivity, so that weed diversity is still in a balanced state or is still in a stable state. Azizah (2017) states that the small or low level of plant species diversity, whether trees, poles or shrubs, indicates that the area where the plants are located is vulnerable to disturbance. The spread and growth of weeds and understorey is influenced by several factors including topography, soil conditions and other environmental factors. 
Table 3 - Weed Species Diversity

\begin{tabular}{ccc}
\hline Number & Name of Species & Diversity of Species \\
\hline 1 & Litu/Ribu-ribu & 0.13 \\
2 & Ilalang & 0.03 \\
3 & Purun Tikus & 0.11 \\
4 & Sampairingan & 0.11 \\
5 & Kelakai & 0.14 \\
6 & Anggrek Tanah & 0.06 \\
7 & Sasuangan & 0.02 \\
8 & Karamunting & 0.08 \\
9 & Kerinyuh & 0.02 \\
10 & Serai Merah & 0.07 \\
11 & Papisangan & 0.05 \\
12 & Sarapangan & 0.06 \\
13 & Rumput Fatimah & 0.03 \\
14 & Bayam rosa & 0.03 \\
15 & Bandotan & 0.02 \\
16 & Kapur Naga & 0.03 \\
17 & Paku piai & 0.03 \\
& Laladingan & 0.03 \\
\hline
\end{tabular}

According to Martono (2012), in addition to genetic factors, plant growth is also influenced by interactions with the environment, one of which is interactions with other organisms. The diversity of weeds and undergrowth has a high influence on the existence of fauna, especially bird species because they can function as a source of food for birds and other animals.

\section{CONCLUSION}

Based on the results of research on vegetation analysis and weed diversity, it can be concluded that there are 18 Species of weeds found in the peat swamp forest, Banjar Regency in 10 total observation plots with 12 families and 2 of them have not been identified, namely Bayam Rosa and Sasuangan. The plant species with the highest NP was Kelakai (Stenochelaena palustris) at $60.13 \%$ and the resulting diversity of species was 1.05 which was included in the medium category.

\section{ACKNOWLEDGEMENTS}

Gratitude is expressed to Lembaga Penelitian dan Pengabdian pada Masyarakat Universitas Lambung Mangkurat (LPPM ULM) that has funded this research through PNBP Research Grants from Skim Program of Dosen Wajib Meneliti.

\section{REFERENCES}

1. Aldrich, R.J. 1984. Weed-Crop Ecology: Principle in Weed Management. Breton Publisch Massachussets.

2. Aththorick, T.A. 2005. Kemiripan Komunitas Tumbuhan Bawah pada Beberapa Tipe Ekosistem Perkebunan di Labuhan Batu. Jurnal Komunikasi Penelitian.

3. Azizah, P.N. (2017). Analisis Vegetasi di Kawasan Sekitar Mata Air Ngembel, Kecamatan Pajangan, Kabupaten Bantul. Jurnal Riset Daerah, 16(1), 2685-2702.

4. Bibiana, A.A., Burhanuddin, dan I. Dewantara. 2015. Struktur dan Komposisi Vegetasi di Areal Petak Ukur Permanen (Pup) Pt. Kawedar Wood Industry Kabupaten Kapuas Hulu. Jurnal Hutan Lestari. Vol 3 (1): 150-159.

5. Fachrul, M. F. (2012). Metode Sampling Bioekologi. Jakarta: PT Bumi Aksara 
6. Indriyanto. 2006. Ekologi Hutan. Bumi Aksara. Jakarta.

7. Martono, D. S. (2012). Analisis Vegetasi dan Asosiasi antara Jenis-Jenis Pohon Utama Penyusun Hutan Tropis Dataran Rendah di Taman Nasional Gunung Rinjani Nusa Tenggara Barat. Jurnal Agri-Tek, 13(2),18-27.

8. Naemah D., Normela Rachmawati, dan Eny Dwi Pujawati. 2020. Keragaman Jenis Tumbuhan Bawah Hutan Rawa Gambut di Kabupaten Banjar. Jurnal Hutan Tropis Volume 8 No. 3, 298-305.

9. Soegianto A. 1994. Ekologi Kuantitatif: Metode Analisis Populasi dan Komunitas. Surabaya: Usaha Nasional.

10. Suyanti, Kissinger dan Gusti Syeransyah Rudy. 2018. Karakteristik Nilai Beberapa Jenis Tumbuhan Penyusun Dukuh (Kebun Buah) di Desa Mandiangin Barat Kecamatan Karang Intan Kabupaten Banjar. Jurnal Sylva Scienteae Vol. 01 No. 1, 117-121

11. Republik Indonesia. Undang-Undang No. 41 Tahun 1999 Tentang Kehutanan

12. Ridhwan. 2012. Tingkat Keanekaragaman Hayati dan Pemanfaatannya di Indonesia. Jurnal Biology Education Volume 1 No. 1. 